\title{
POLICE MISCONDUCT AND DELICTUAL LIABILITY: A DISCUSSION ON DEVELOPING VICARIOUS LIABILITY JURISPRDUENCE THROUGH A FOCUS ON THE $K$ AND $F$ CASES
}

\author{
By Kameel Premhid*
}

\section{Introduction}

Despite progress made by South African courts with respect to the 'sufficiently close connection' requirement to establish vicarious liability, most notably in the judgment of the Constitutional Court (CC) in $K v$ Minister of Safety and Security, ${ }^{1}$ the question remains whether our judges have accepted this ground-breaking precedent and apply it in the spirit it was intended. ${ }^{2}$

In focusing on the minority dissenting judgment in $F v$ Minister of Safety and Security $(F)^{3}$ written by Yacoob J (with Jafta J concurring), I address wider issues that exist with respect to the sufficiently close connection requirement of vicarious liability as established by $K$. As part of this discussion, I also proceed to: (1) set out the material facts of $F$; (2) give an overview of the current law applicable to vicarious liability and show where $F$ fits into that framework; (3) briefly discuss all the judgments of the Constitutional Court with respect to the framework of vicarious liability as provided; and (4) offer a critique of the minority dissenting judgment with the aim of making more general comments about the sufficiently close connection requirement in the case of (standby duty) policemen. It is submitted that some of the factors considered in the context of policemen could potentially be applicable in other scenarios where the question of a sufficiently close connection for the purposes of vicarious liability arises.

* $\quad$ BA LLB (University of KwaZulu-Natal), KZN Rhodes Scholar-Elect 2012 and Intern at the Helen Suzman Foundation.

$1 \quad K$ v Minister for Safety and Security 20056 SA 419 (CC)

J Neethling \& JM Potgieter 'Delictual state accountability for police rape' (2012) 9 LitNet Academic http://www.litnet.co.za/Article/deliktuele-staatsaanspreeklik heid-weens-polisieverkragting_(accessed 26 April 2013).

$3 \quad F \vee$ Minister of Safety and Security 20121 SA 536 (CC). As per footnote 2 of Mogoeng CJ's judgment, the Court still referred to the Minister as the Minister of Safety and Security even though the Minister's portfolio had been renamed to the Ministry of Police. 
With reference to the critique and commentary offered, I will conclude by illustrating how courts can overcome 'semantic discussions of the meanings of the 'course and scope' ... requirements' ${ }^{4}$ within the existing vicarious liability framework. It is hoped that when a court is adjudicating such a dispute it will apply the principles of vicarious liability in such a way that will

take into account the importance of the constitutional role entrusted to the police and the importance of nurturing the confidence and trust in the police, in order to ensure that their role is successfully performed. ${ }^{5}$

\section{Material facts 6}

This case was an appeal heard from the Supreme Court of Appeal (SCA). ${ }^{7}$ The SCA in turn heard this matter on appeal from the Western Cape High Court (High Court) where the matter was argued before Bozalek J. ${ }^{8}$

The facts are as follows: Van Wyk, the second respondent in this matter, ${ }^{9}$ was a detective on standby duty during the evening and/or early morning of $14 / 15$ October $1998 .{ }^{10}$ Van Wyk met Ms $F$, a 13 year old minor girl child at the time, at a nightclub. Van Wyk was at the nightclub despite being on standby duty. $F$ was in need of a lift and thus accepted his assistance. ${ }^{11}$ Van Wyk was at the time in possession of an unmarked police vehicle to enable him to discharge any police functions that he might be required to perform. ${ }^{12}$ Van Wyk also transported two other passengers whilst giving $\mathrm{F}$ a lift, one of whom was known to her. ${ }^{13}$ Van Wyk dropped off the other passengers at their respective homes. At the request of Van Wyk, F moved into the front seat of the vehicle at which point she noticed police dockets on the seat. In reply to her question as to whether he was a policeman, Van Wyk responded that he was a private detective. $\mathrm{F}$ took this to mean that he was a policeman. ${ }^{14}$

Despite his undertaking to take her home, Van Wyk aroused F's suspicions when he drove towards Kaaimansrivier, away from her

\footnotetext{
M Loubser \& R Midgley (eds) The law of delict in South Africa (2009) 379. K (n 1 above) para 52.

Loubser and Midgley (n 4 above) 379.

$F$ (note 3 above). The facts of the case appear more fully from the judgment but are canvassed here briefly. Specifically see paras 8 - 25 and $157-162$.

Minister of Safety and Security v F 2011 (3) SA 487 (SCA).

$F \vee$ Minister of Safety and Security 2010 (1) SA 606 (WCC).

$F$ (note 3 above).

$F$ (n 3 above). Appellant's Heads of Argument para 57.

$F$ (n 3 above) para 8.

$F$ (n 3 above) para 9.

$F$ (n 3 above) para 8.

$F$ (n 3 above) para 10.
} 
home. ${ }^{15}$ Van Wyk assured her that they would be a short time as Van Wyk just wanted to visit friends. Given her suspicions, F escaped from the vehicle and hid. Van Wyk then seemingly departed and F sought another lift. Her position being desperate and in need, gave rise to the subsequent rape and assault that Van Wyk subjected her to, as when he approached her the second time, despite her suspicions, she accepted a lift from him. ${ }^{16}$

The CC accepted her evidence that she trusted him to deliver her to her home, despite her suspicions, by virtue of him being a policeman. ${ }^{17}$ Upon her second attempt at escaping, Van Wyk managed to prevent her from doing so and then proceeded to rape and assault her. He then dropped $\mathrm{F}$ off at her home after threatening her with death should she report it to the authorities. ${ }^{18}$ Despite these threats, F laid criminal charges against him. Van Wyk was convicted and sentenced to 12 years' imprisonment ( 5 of which were suspended). ${ }^{19}$ In December 2005, F sought to launch proceedings to recover damages from the Minister and Van Wyk himself. ${ }^{20}$

In order to fully understand how these facts were interpreted differently and why clarity on the sufficiently close connection test is needed, a brief overview of the case history of this matter before it was heard in the apex court is necessary.

\section{Case history}

\subsection{The High Court}

In the High Court, the applicant (F) was successful in her claim for damages against the Minister (first respondent) and Van Wyk (second respondent). Whilst it is obvious that $\mathrm{F}$ had a delictual claim against Van Wyk, the Court, as per Bozalek J, found the Minister to be vicariously liable for Van Wyk's conduct. Bozalek J made this finding through an application of the sufficiently close connection test as established in $K$. As an indication of this link, Bozalek $\mathrm{J}$ cited three factors: (a) Van Wyk being provided with a police vehicle (even if unmarked) by his employer enabled the delict to be committed; (b) the fact that $F$ trusted Van Wyk by virtue of his status as a policeman - the condition without which she would have not allowed herself to be in such a position in the first place; and (c) the overlap

$F$ (n 3 above) para 11

$F$ (n 3 above) para 12

$F$ (n 3 above) para 13.

$F$ (n 3 above) para 14

$F$ (n 3 above) para 15.

$F$ (n 3 above) para 16. 
between Van Wyk's mala fide offer of assistance and his official duties as a policeman. ${ }^{21}$

\subsection{The Supreme Court of Appeal}

Having been granted leave to appeal, the Minister sought to have the court a quo's decision set aside. The SCA found by a 3 - 2 majority, as per Nugent JA, that the Minister was not vicariously liable.

Nugent JA overturned the decision of the court a quo on the following grounds: (a) $K$ was distinguishable for two reasons: (i) the policemen in $K$ were on duty; and (ii) an off duty policeman has 'no duty to protect members of the public ... This is so because the police do not have an ongoing duty to protect members of the public. And in the absence of a duty ... there could be no personal liability on him;'22 (b) that $K$ did not extend to positive delictual acts but only to acts of omission and that because Van Wyk was not on duty he could not have 'breached his duty to protect $\mathrm{F}$ when he committed the rape. ${ }^{23}$

\subsection{The tension between the SCA and CC majorities}

This case when then taken on a further appeal to the Constitutional Court. Mogoeng $\mathrm{CJ}$, writing on behalf of the majority who overturned the SCA's decision, stated that the majority in the SCA understood $K$ to apply because the policemen 'committed a delict of omission' and failed to protect $\mathrm{K}$ whilst 'they were on duty and under an obligation to do so. ${ }^{24} \mathrm{He}$ notes on behalf of the majority that they 'reject(s) any notion that a policeman could be ... "engaged in the affairs of his employer" when he commits a rape' or that it could be regarded as "an "improper mode" of the authority conferred on him by the employer.'

Mogoeng $\mathrm{CJ}$ found the judgment of the SCA minority (written by Maya JA) to be more persuasive. He favourably summarised her judgment as follows: '... although the rape had nothing to do with (his) official duties, there was a sufficiently close link between his acts for personal gratification and the police. ${ }^{25}$ Mogoeng CJ placed significant emphasis on Maya JA's finding that F only trusted Van Wyk

$21 \quad F$ (n 3 above) para 18. Further, see Applicant's Affidavit para 12.

$22 F$ (n 3 above) para 20 . The implication of this argument although not expressly summarised by Mogoeng CJ as such, is that in the absence of a personal duty to protect $F$, when Van Wyk raped her, he did so as a private citizen and thus by extension, no vicarious liability extends to the Minister.

$23 \quad F$ (n 3 above) paras $20 \& 22$.

$24 F$ (n 3 above) para 21

$25 \quad F$ (n 3 above) para 23. 
by virtue of the fact that he was a policeman and that when he offered $\mathrm{F}$ a lift, he placed himself on duty. ${ }^{26}$

It is this difference which allowed the minority of the SCA and the majority of the CC to differ on the merits of F's case in the context of the applicability of $K$.

\section{The current position on vicarious liability 27}

Vicarious liability is considered to be a form of strict liability where the employer is held liable for the wrongdoing of the employee. ${ }^{28}$ The employer is held to be jointly liable when the delict is committed within the course and scope of employment ${ }^{29}$ or where they undertake any activities incidental to it. ${ }^{30}$ There are many theories which explain the existence of vicarious liability but the general position is that where a particular relationship of employment exists, ${ }^{31}$ and the employee, in the pursuance of his objectives of employment, commits a delict, the employer shall bear joint responsibility for the offending conduct. ${ }^{32}$

Delicts committed while going about the employer's business are regarded as the standard cases. Where however the wrongdoing ostensibly takes place outside the course and scope of the employment relationship, i.e. the so called deviation cases, 33 liability may still be imputed to the employer where there is a sufficiently close connection that can be established between the wrongful act and the employment. This was established in $K$ which can be credited

6 Ibid

$27 \quad F$ (n 3 above) paras 40 - 50. Mogoeng CJ sets out the development of vicarious liability in detail in his judgment.

Loubser \& Midgley (n 4 above) 367.

Loubser \& Midgley (n 4 above) 367.

$F$ (n 3 above) para 40 . Mogoeng $C \mathrm{~J}$ in footnote 26 lists cases which illustrate that principle: Ess Kay Electronics Pte Ltd and Another $v$ First National Bank of Southern Africa Ltd 2001 1 SA 1214 (SCA) (Ess Kay Electronics) para 7 (which dealt with whether an employee of the bank who stole and forged two banker's drafts acted within the course and scope of his employment); and ABSA Bank Ltd $v$ Bond Equipment (Pretoria) (Pty) Ltd 20011 SA 372 (SCA) para 5 (which also dealt with a similar question with respect to the unlawful conduct of an employee and whether that qualified in terms of the course and scope test).

Neethling, Potgieter \& Visser Law of Delict (4th edition) (2001) 373

The requirements of vicarious liability are set out differently but have the employer-employee relationship and committing the delict within the course and scope of the employment in common. Neethling et al (n 31 above) $374-379$ list 3 requirements, namely: (1) there must be an employer-employee relationship at the time when the delict is committed; $(2)$ the employee must commit a delict; and (3) the employee must act within the course and scope of his employment when the delict is committed. This is different to Loubser \& Midgley ( 4 above) 369 - 370; 374 - 376 who list 2 requirements, namely: (1) an employment or akinto-employment relationship must exist; and (2) the delict must be committed by $33 \quad F$ (n 3 above) para 41 . 
with reforming the vicarious liability test to bring it in line with constitutional demands of the Bill of Rights. ${ }^{34}$

\subsection{The position with respect to vicarious liability cases is as follows}

In Feldman (Pty) Ltd $v$ Mall, ${ }^{35}$ the Appellate Division ('AD') held that an employer could be held liable for the delicts of an employee even where employees are 'inefficient or untrustworthy' in satisfying their employment obligations because 'employees are extensions of their employers' and that 'employers could be held to have created a risk of harm to others. ${ }^{36}$ It seems that this dictum could apply so widely that even where they 'act inconsistently with their employer's core business' they could still be liable where 'some link between the employer's business and the delictual conduct (may) be established. ${ }^{37}$ The main idea to take away from this case is not the idea of the creation of risk, ${ }^{38}$ but rather that an employee can bind an employer for their delictual acts if in carrying out their employment they act in an imperfect manner. ${ }^{39}$ This case contributed to our understanding of typical vicarious liability scenarios.

Further, in Minister of Police $v$ Rabie ${ }^{40}$ the test for vicarious liability was further developed and reformulated in these terms:

It seems clear that an act done by a servant solely for his own interests and purposes, although occasioned by his employment, may fall outside the course or scope of his employment, and that in deciding whether an act by the servant does so fall, some reference is to be made to the

$F$ (n 3 above) para 48.

Feldman (Pty) Ltd $v$ Mall 1945 AD 733. Briefly, this case dealt with the situation where an employee driver whilst on official duty deviated from his official duties and catered to his personal affairs which inter alia involved consuming alcohol which impaired his driving abilities. When he resumed official duties and was returning to work, he negligently collided with and killed a man with two minor dependents. This case centered on whether the company was vicariously liable for the dependants' claim for damages.

36 Loubser \& Midgley (n 6 above) 367.

$37 \quad F$ (n 3 above) paras $42,44-45$

$\mathrm{K}$ Calitz "Vicarious liability of employers: reconsidering risk as the basis for liability' (2005) 3 TSAR 215, 231. Calitz opines that whilst the idea of risk as the basis of vicarious liability is 'not alien to South African jurisprudence' it has not been 'thoroughly examined' and as such was 'rejected in later decisions.' In footnote 96 she references two cases as authority: $R \vee$ Ngobo 19924 SA 822 (A) 39 and Ess Kay Electronics (note 30 above) para 40.

$39 \mathrm{~S}$ Wagener ' $\mathrm{K} \vee$ Minister of Safety and Security and the increasingly blurred line between personal and vicarious liability' (2008) SALJ 674.

40 Minister of Police $v$ Rabie 19861 SA 117 (A). Briefly, this case dealt with the situation where an off-duty employee policeman (who was a mechanic) wrongfully arrested, detained and assaulted the respondent in pursuit of his personal interests. The mechanic-policeman even went so far as to identify himself as a policeman despite being off duty and not in uniform. This case, heard on appeal, centred on whether the Minister was vicariously liable for the claim for damages where the conduct complained of radically deviated from the tasks directly and indirectly connected to the wrongdoers' employment. 
servant's intention. The test is in this regard subjective. On the other hand, if there is nevertheless a sufficiently close link between the servant's acts for his own interests and purposes and the business of his master, the master may yet be liable. This is an objective test. ${ }^{41}$

This reformulation allowed our Courts to adjudicate on so-called 'deviation' cases where the wrongful act was, prima facie, outside the employment relationship.

The Rabie 42 test was essential to the subsequent development of that developed in $K .{ }^{43}$ This can be seen as follows:

The approach makes it clear that there are two questions to be asked. The first is whether the wrongful acts were done solely for the purposes of the employee. This question requires a subjective consideration of the employee's state of mind and is a purely factual question. Even if it is answered in the affirmative, however, the employer may nevertheless be liable vicariously if the second question, an objective one, is answered affirmatively. That question is whether, even though the acts done have been done solely for the purpose of the employee, there is nevertheless a sufficiently close link between the employee's acts for his own interests and the purposes and the business of the employer. This question does not raise purely factual questions, but mixed questions of fact and law. The questions of law it raises relate to what is 'sufficiently close' to give rise to vicarious liability. It is in answering this question that a court should consider the need to give effect to the spirit, purport and objects of the Bill of Rights. ${ }^{44}$

Cases like $F$ bring the $K$ test into sharp perspective because even though it is obvious that the conduct of Van Wyk would traditionally exclude vicarious liability as his wrongful conduct could never be in the interests of his employer, the possibility exists that if the second question is answered affirmatively - and a sufficiently close link is found to exist - then the Minister could still be found liable. O'Regan $\mathrm{J}$, in a powerful judgment, developed several factors that a court should evaluate in order to determine whether a sufficiently close link existed. They are: (1) the state's constitutional obligations to protect the public; (2) the trust that the public is entitled to place in the police; (3) the significance, if any, that the policeman may be off duty or on standby duty; (4) the role of the policeman's commission of the rape and omission to protect the victim; and (5) the existence of an intimate link between the policeman's conduct and his employment. These elements are complimentary and all work together to prove vicarious liability. ${ }^{45}$

\footnotetext{
Rabie (n 40 above) 134 C - E; F (n 3 above) para 47.

$F$ (n 3 above) para 49.

$K$ (n 1 above). Briefly, the question posed by this case was whether the State could be held vicarious liable where 3 on duty policemen (who were in uniform and utilising a marked police vehicle) raped a woman that they had offered to give a lift to after she had been separated from her party at a nightclub.

45 (n 3 above) para 52.
} 
The question then for the Constitutional Court then is whether the $K$ test can be extended to a standby duty policeman. Even though the $C C$ in $F$ did find that it could - the minority dissenting judgment illustrates that in practice, in the absence of further considerations to supplement the test, the opportunity for doubters of $K$ still exists to not apply it. In as much as judicial dissent and disagreement can and must be encouraged in furthering our law, ${ }^{46}$ especially when the minority judgment is radical in its thinking and acts as the foundation for future developments of the law, we must be wary where such dissent could have the effect of retarding the advancement that we have made.

\section{Judgments of the Constitutional Court}

\subsection{Majority judgment}

Mogoeng $\mathrm{CJ}$ writing on behalf of the majority, ${ }^{47}$ found the Minister to be vicariously liable. Mogoeng CJ established this through an examination of each of the factors laid down in K. Mogoeng CJ's findings can be summarised as follows: ${ }^{48}$

- On the question of the state's constitutional obligations to protect the public Mogoeng $\mathrm{CJ}$ held that the police do have a significant duty to protect women and girls specifically from the 'plague of violent crimes' and that their 'fundamental rights are not made hollow by actual or threatened sexual violence'. ${ }^{49}$ While Courts may have fashioned the rules of vicarious liability according to common law, they must now ensure that those rules apply and are defensible in a society guided by our constitutional norms and standards. ${ }^{50}$ This is encapsulated by section $205(3)$ of the Constitution, ${ }^{51}$ which states that the objects of the police are to, inter alia, 'promote, combat and investigate crime ... and to uphold and enforce the law'. ${ }^{52}$ This provides a constitutional basis upon which to hold the State liable should this duty of police to combat crime and enforce the law be breached.

- With respect to the trust that the public is entitled to place in the police, Mogoeng CJ found that:

46 M Ryder 'The value of dissent' The Guardian 16 November 2012 http:// www.guardian.co.uk/law/2010/nov/16/dissenting-judgments-radmacher-hale (accessed 26 April 2013).

47 Moseneke DCJ, Cameron J, Khampepe J, Nkabinde J, Skweyiya J and Van der Westhuizen $\mathrm{J}$ concurring.

$48 \quad F$ (n 3 above) para 53 - 82. The Chief Justice engages in a very detailed explanation. As far as possible, the author has tried to summarise each factor so as to convey the full finding of Mogoeng $\mathrm{CJ}$ in his drawing the inevitable conclusion that the Minister is vicarious liable.

$49 \quad F$ (n 3 above) para 57

$50 \quad F$ (n 3 above) para 57

51 Constitution of the Republic of South Africa, 1996.

$52 \quad F$ (n 3 above) para 59. 
the employment of someone as a police official may rightly be equated to an invitation extended by the police service to the public to repose their trust in that employee. When a policeman abuses the trust placed in him by ... by raping ... a link may well be established between the employee's employment and the delict. ${ }^{53}$

- As to the significance of the fact that that the policeman may be on/ off or on standby duty, Mogoeng CJ stated that:

[He accepts] that a distinction between a policeman who is on duty and one who is off duty is a relevant factor in determining the closeness of the connection (but that he) does not accept it is determinative of [liability] ... [especially where F] was led to believe that a policeman, whether on or off duty, assumed the responsibility to protect her [which was] sufficient to let her guard down. ${ }^{54}$

- Given that the SCA distinguished the applicability of $K$ on the grounds that they believed it to only apply in the case of omissions, ${ }^{55}$ it is important to note Mogoeng CJ's quoting of $K$ :

[The] conduct of the policemen which caused harm constituted a simultaneous commission and omission. The commission lay in their brutal rape of the applicant. Their simultaneous omission lay in their failing while on duty to protect her from harm, something which they bore a general duty to do, and a special duty on the facts of this case. In my view, these three inter-related factors make it plain that viewed against the backdrop of our Constitution, and, in particular, the constitutional rights of the applicant and the constitutional obligations of the respondent, the connection between the conduct of the policemen and their employment was sufficiently close to render the respondent liable. ${ }^{56}$

Mogoeng CJ goes on to describe the interplay between the role of the policeman's commission of the rape and omission to protect the victim as being 'two sides of the same coin and both stem from and revolve around the same incident';57

- Lastly, on the question of the existence of an intimate link between the policeman's conduct and his employment, the Chief Justice again quotes from $K:{ }^{58}$

When the policemen ... raped the applicant, they were simultaneously failing to perform their duties to protect the applicant. In committing the crime, the policemen not only did not protect the applicant, they infringed her rights to dignity and security of the person. In so doing, their employer's obligation (and theirs) to prevent crime was not met. There is an intimate connection between the delict committed by the policemen and the purposes of their

$F$ (n 3 above) para 64. Mogoeng $C J$ went on to quote from $K$ as follows: 'the opportunity to commit the crime would not have arisen but for the trust the (Minister) placed in them because they were policemen.' $K$ ( $\mathrm{n} 1$ above) para 57. $F$ (n 3 above) para 67.

$F$ (n 3 above) para 73.

$K$ (n 1 above) para 32; $F$ (n 3 above) para 70.

$F$ (n 3 above) para 72 .

$K$ (n 1 above) para 57; $F$ (n 3 above) para 77. 
employer. This close connection renders the respondent liable vicariously to the applicant for the wrongful conduct of the policemen.

The Chief Justice, in the final blow to the Minister's case applies this and finds:

The police vehicle, which was issued to him precisely because he was on standby duty, enabled Mr van Wyk to commit the rape. It enhanced his mobility and enabled him to give a lift to Ms F. Further, when Ms F reentered the vehicle, she understood Mr van Wyk to be a policeman. She made this deduction from the dockets and the police radio in the vehicle. In other words, he was identifiable as a policeman. And, in fact, he was a policeman. Pivotal is the normative component of the connection test. Beyond her subjective trust in Mr van Wyk is the fact that any member of the public and in particular one who requires assistance from the police, is entitled to turn to and to repose trust in a police official. ${ }^{59}$

\subsection{Minority concurring judgment}

The concurring minority judgment of Froneman $\mathrm{J}$ is a bold exercise of judicial activism aimed at holding the state liable on the grounds of direct liability. The central theme of Froneman J's judgment is that the state acts through its functionaries and has no capacity to act independently of them. As such, where a state functionary commits a delict it is as though the state has committed that delict itself. ${ }^{60}$ Froneman $J$ recasts the test in a shrewd way for he both simultaneously employs the extension of vicarious liability that $K$ introduced whilst equally discarding its most problematic aspect, namely the sufficiently close connection test. Froneman J argues that it would be more appropriate for a wrongfulness test to be used as it is also likely that a wrongfulness test will more easily yield an accurate result. ${ }^{61}$ The wrongfulness test focuses on the 'duty not to cause harm to another and its breach'.62

Much like the Chief Justice, I am unwilling to engage in a discussion on the merits of the argument as proposed by Froneman $\mathrm{J}$ as none of the parties raised it before the CC itself. ${ }^{63}$

$F$ (n 3 above) para 81.

$F$ (n 3 above) para 90.

$F$ (n 3 above) paras $89-91$

Ibid.

$F$ (n 3 above) para 83. Suffice it to say that whilst Froneman J's reformulation of the test deals directly with the dissent of Yacoob J and Jafta J (and the judgment of the S(A), the same result can be achieved by utilising the sufficiently close connection test as supplemented by the submission in this article. 


\subsection{Dissenting minority judgment}

The dissenting minority judgment of Yacoob J (Jafta $\mathrm{J}$ concurring) deals specifically with two factors of the $K$ test. First, whether there was a duty that existed (this is done through an examination of what the meaning of standby duty is); and secondly, whether the trust that is placed by $\mathrm{F}$ in Van Wyk is reasonable. ${ }^{64}$ Yacoob $\mathrm{J}$ finds that no vicarious liability can attach to the Minister because he answers both questions in the negative - namely that there was no duty by virtue of Van Wyk being off duty and that F's reliance on Van Wyk was unreasonable.

I will examine each of these factors in turn as a means of critiquing the minority judgment. It is hoped that in the rebuttal offered herein, any Court dealing with a similar matter in future will be able to use the approaches offered to supplement the test and make an appropriate finding of vicarious liability.

\section{The meaning and impact of standby duty}

The response offered in terms of this question deals with the arguments of both Nugent JA in the SCA and Yacoob J in the CC. The reason for dealing with both sets of arguments pertaining to standby duty is owing to the fact that there is a significant degree of overlap between them and in dealing with both sets of arguments, I am of the opinion that this on duty/off duty question is settled more thoroughly.

Nugent JA drew specific attention to the fact that Van Wyk was on standby duty when he raped F. By virtue of this, Nugent JA asserted that Van Wyk was effectively off duty and he had no legal obligation to protect $F$. From this, no vicarious liability could attach to the Minister. The rape was thus committed in his private capacity and had no bearing to his official employment. ${ }^{65}$

Mogoeng $\mathrm{CJ}$ deals with this technical distinction between being on and off duty and the subsequent legal obligations that places on members of our police force by posing the following question: 'Can we say that because a policeman is not on duty, he has no obligation as a policeman to protect a child against rape? I do not think so. ${ }^{66}$ Whilst Mogoeng CJ's answer to the on/off duty question has been canvassed above, I am of the opinion that a far more critical approach needs to be taken to the fact that Van Wyk was neither on duty nor off duty at the time, but rather that he was on standby duty.

$F$ (n 3 above) para 175.

$F$ (n 3 above). Appellant's Heads of Argument para 9.

$F$ (n 3 above) para 67. 
As Mogoeng CJ notes standby duty entitled Van Wyk to the use and enjoyment of a state vehicle and remuneration. ${ }^{67}$ This means that at any time he could be called upon to provide active assistance as and where the case arose. This is either where he may have been placed on duty by his commanding officer ${ }^{68}$ or where he exercised his discretion to do so. ${ }^{69}$ This means that a policeman (whether on or off duty) has an ability to assist any victim of a crime that they are witness to. It is for that purpose that the res ipso facto common law provision exists with respect to policemen; namely, that an off-duty policeman (excluding a reservist) has the ability to place himself on duty in circumstances that warrant it (such as where they are witnessing a crime being committed). They may do this without having to undergo the normal procedures to place themselves on duty (i.e. to get due authority from their commanding officer, to book themselves on air with radio control). This provision speaks to the fact that in a constitutional democracy we can have a legitimate expectation that those in positions of authority/care/trust should exercise the powers of their office when the need arises and where they have the ability to do so. ${ }^{70}$

Accordingly, Van Wyk could not act as a private citizen when he was on standby duty. His status as a private citizen was held in abeyance given that 'at any time of night (he could) have been called upon to attend to any crime-related incident. ${ }^{71}$ This means that he was equally not released from the obligations that attached to him as a policeman on duty. Just as an on duty policeman would have to respond to a crime and be bound by his common law and constitutional duties to protect citizens, so too would a standby duty policeman. ${ }^{72}$

$F$ (n 3 above) para 67

Sec 13(2) of the South African Police Act 68 of 1995 read together with sec 13(1). Ibid. Sec 13(13). Also, Rabie v Minister of Police \& Another 19841 SA 786 (W) 791-F; analogously, the discretionary power given to policemen to effect an arrest in terms of s 40(1)(a) of the Criminal Procedure Act 51 of 1977 as held by $R v$ Bailey 1920 CPD 193, 195 - 196 (as to the technical distinction between on duty/ in uniform when one must exercise that discretion); and Gellman $v$ Minister of Safety and Security 20081 SACR 446 (W) para 94.

70 For the development of the legitimate expectation doctrine see amongst others Administrator, Transvaal $v$ Traub and Others 19894 SA 731 (A). A legitimate expectation is one where there is an express undertaking that a particular process will be used or result will be followed; or that settled conduct is to be expected. With respect to the police, this legitimate expectation arises from various sources (case law, statute, treaties, best international practice, etc). Further, this form of legitimate expectation that the public may have of the police is justiciable irrespective of the source. In this case a legitimate expectation is enhanced by sec 205(3) of the Constitution of the Republic of South Africa when read with sec 2 .

$71 \quad F$ (n 3 above) para 9.

72 While it seems like the Constitutional Court found that as an off duty policeman he would be bound, I opt to keep that question open and limit the discussion to standby duty policeman which is a technically nuanced consideration. 
It is my opinion therefore that if there is any doubt as to whether being on standby duty bears a corollary relationship to being on duty or being off duty, a court would err on the side of caution and align standby duty to being closer to functioning as an on duty policeman. In that way, the Minister will not be able to escape liability for the wrongdoing of his employees even though he enjoys the benefits of their status as not being private citizens. Standby duty policeman cannot be considered on duty when it comes to fighting crime but being off duty when it comes to the State being held liable for their delictual conduct.

This submission deals with the first aspect of Yacoob J's dissent as outlined above. ${ }^{73}$ The learned Justice seems to assert that standby duty policemen are off-duty until they are called upon for active service ${ }^{74}$ It is submitted that their role is to act as a reserve force that may be called upon at any time to assist on duty policemen where circumstances require it. While they are on standby duty, they are still operating under a duty to provide a service and are thus acting under the auspices of the employer's authority. To argue that they are off-duty denies the role they actually play. If they are considered off duty, it undermines Yacoob J's own argument that 'he had to be available to go on duty if called to do so. ${ }^{75}$ Off-duty policemen are under no duty to, within normal circumstances, be available to go on duty whereas standby duty policemen are. ${ }^{76}$

This acknowledgment shows a contradictory train of thought as to how standby duty policemen should be viewed: on one hand Yacoob J says they operate under a duty to act (like on-duty policemen) but on the other he says that they are to be considered off-duty (and thus do not have a duty). Yacoob J's concession shows that standby duty policemen are acting under some duty which distinguishes them from being off-duty. It is preferable, as I argue, that when standby duty policemen commit a delict the state can be held liable so that if a person has their rights infringed by a policeman acting under any duty, they are entitled to some form of recourse.

Yacoob J's finding has the potential effect of putting him at odds with our jurisprudence on cases of this nature. By stating that 'the only question to be determined in this case is whether the circumstances lead to the conclusion that there was a sufficient connection between his wrongful acts and commissions and the business of the employer to render the employer liable ${ }^{, 77}$ he possibly

$F$ (n 3 above) paras 155 - 156

$F$ (n 3 above) para 155 - 156.

$F$ (n 3 above) para 156.

Agreement of the Safety and Security Bargaining Council 2002-05-08 http:// www.sssbc.org.za/ClientFiles/Documents/agreements/2002/Agreement_5.2002_ Working_hours_in_the_SAPS.pdf (accessed 29 April 2013).

$77 \quad F$ (n 3 above) para 156. 
suggests that even where a person may commit unlawful acts during the course and scope of his employment, the employer may escape liability where there is no connection or not a strong enough connection between them. It is submitted that this statement is diametrically opposed to the reasoning of $K$ that Yacoob $J$ happens to quote favourably. ${ }^{78}$ The interests of the employer in cases such as these would never be to rape a person. If the emphasis of the test is the connection between the interests of the employer and the employee it may even render the state not liable where the on-duty policeman commits a delict given the divergence in interest that Yacoob J seems to emphasise. The second leg of the $K$ test must take preference: namely, where there is a sufficiently close connection. ${ }^{79}$

As evidence for the fact that in this case the offence was committed within the course and scope of employment and that there was a sufficiently close link between the delict and interest of the employer, one can rely on the judgment of Yacoob J himself. Whereas it is not evident from the judgment of Mogoeng CJ's as to why the policeman was driving his unmarked police vehicle at that time the delict was commited, Yacoob J's judgment provides further clarity. Van Wyk was on standby duty for a set period and during that time he was performing police work. However, at some stage during the evening, Yacoob $\mathrm{J}$ states 'he stopped performing this function at 20:00' and then went on to improperly use the vehicle to go to a night club. ${ }^{80}$

As illustrated above, being on standby duty means that a policeman is obligated to perform certain functions and that in exchange for this they are adequately remunerated. Yacoob J's seeming acceptance of Van Wyk's unilateral disengagement of his duties as terminating any duty that may have existed and thus exonerating the Minister cannot be accepted. It is submitted that any policeman's subjective feelings/frame of mind at the time that they disengage from their duties does not count. As it was held in Feldman, ${ }^{81}$ the employee disengaging from their duties and committing a delict will not exonerate the employer from liability. Despite Van Wyk's unilateral disengagement he was in fact on standby duty when he committed the rape and accordingly the state should be found liable. An acceptance of the contrary position, that a unilateral disengagement from one's duty is binding, undermines the very command-and-control structure that the police service is premised upon.

$F$ (n 1 above) paras 152 - 154.

$F$ (n 3 above) para 48.

$F$ (n 3 above) para 157.

Feldman (n 35 above). 
The significance here of the duty element when contrasted with other instances of vicarious liability is only too significant. Whereas unilateral disengagement has been accepted by our Courts in instances where the duty arose out of a commercial contract of employment, ${ }^{82}$ our courts have been justifiably unwilling to accept the same with respect to the police given the constitutional obligations enjoining them to serve the people of this country. It is submitted therefore that Van Wyk was under a duty and that by breaching it, provided that a sufficiently close connection was established (as it has been), the Minister should be held liable

\section{$7 \quad$ Was F's trust unreasonable?}

The other aspect of Yacoob J's dissent focuses on whether the trust specifically arising between $\mathrm{F}$ and Van Wyk was reasonable. I am of the opinion that given the acceptance in $K$ that no hard and fast rule could be developed so as to avoid the position that absolute liability would be the result; ${ }^{83}$ such a position warrants a case-by-case analysis of the facts. I shall argue that based on the facts of the case it was and that accordingly, the abuse of the trust perpetrated by Van Wyk, further gives rise to vicarious liability on the part of the Minister.

On the facts of $F$, it is not difficult to draw the conclusion that by virtue of Van Wyk being on standby duty and the Minister vesting in him certain trappings of office (by permitting use of a police vehicle, albeit unmarked, and possession of police dockets), the Minister created the impression that he was a policeman. According to the standard rules of an estoppel defence, borrowing from the law of agency, where such an impression is created by the principal and an innocent third party relies on that impression to their detriment, the principal (in casu, the Minister) will be estopped for denying liability for the conduct of the agent (in casu, the employee policeman). ${ }^{84}$

From the judgment of Mogoeng $\mathrm{CJ},{ }^{85}$ it is possible to infer that he (and the majority of the court) agrees that this kind of justification

See Costa da Oura Restaurant (Pty) Ltd t/a Umdloti Bush Tavern v Reddy 20034 SA 43 (SCA). Even though the High Court saw the assault by the barman Goldie as being directly related to and emanating from his duties as a barman, the SCA was of the opinion that the assault occurred once he has abandoned his duties and thus his act was one of personal gratification that could not be attributable to his employer. Whereas this kind of unilateral disengagement could be accepted in the context of private citizens, it is doubted whether it would apply in the context of a public functionary such as a policeman in light of the constitutional mandate they are given.

$83 \quad F$ (n 3 above) para 84

84 See Monzali v Smith 1929 AD 382; Peri-Urban Areas Board v Estate Breet 19583 738 (T); Dicks v Mutual Fire \& General Insurance 1963 (4) SA 501 (N); Beyleveld v Southern Life 19891496 (A); Glonfico v ABSA Bank t/a United Bank 20026 SA 470 25 (SCA)

F (n 3 above) para 81. 
may exist. In establishing the sufficiently close connection he mentions that $F$ understood that her rapist was a policeman. ${ }^{86} \mathrm{He}$ establishes this by citing the fact that $F$ had noticed the police dockets and the police radio in the car. He establishes that these are obvious indicators that her rapist was a policeman. The argument Mogoeng CJ makes correctly is that where a person is identifiable as a policeman it is reasonable for any person to place trust in that policeman and expect assistance from them in accordance with the degree of care that is to be expected of the police force. ${ }^{87}$ The reliance may especially be induced where the person relying on the representation may be vulnerable. The courts must accordingly do whatever is possible to ensure that where that trust is broken adequate mechanisms are established to restore it. This could apply even where an off-duty policeman were to commit a delict provided there was a sufficiently close link between the employment and the wrongful conduct. 88

Yacoob $\mathrm{J}$ disagrees with this and advances two arguments as to why F's reliance was not reasonable:

(a) The first argument, which is the weaker of the two, is to place emphasis on the fact that the policeman was not on duty ${ }^{89}$ and could not have been easily identified as a policeman. ${ }^{90}$ The first aspect of this approach is already dealt with. The issue of whether or not the policeman was easily identifiable can be dispensed with as follows: is an on-duty plain clothes policeman under any less of an obligation to act in accordance with their duty as a policeman than one in uniform? ${ }^{91}$

The answer must be no. The fact that a policeman does not immediately appear to be a policeman (such as being in uniform) does not lessen the obligations they are under especially when they are under a duty to perform. ${ }^{92}$ The reliance of Yacoob J on the facts of $K$ to distinguish between these two cases is tenuous at best. The police are under a general duty to disclose their status as being policemen and assist members of the community when asked to do so. When $F$ asked the policeman whether he was a policeman, this activated that duty which meant he was then under an obligation to come to her aid. In lying to her and in then subsequently raping her, the policeman in this case breached his state-sanctioned duty to $F$. It is for this reason

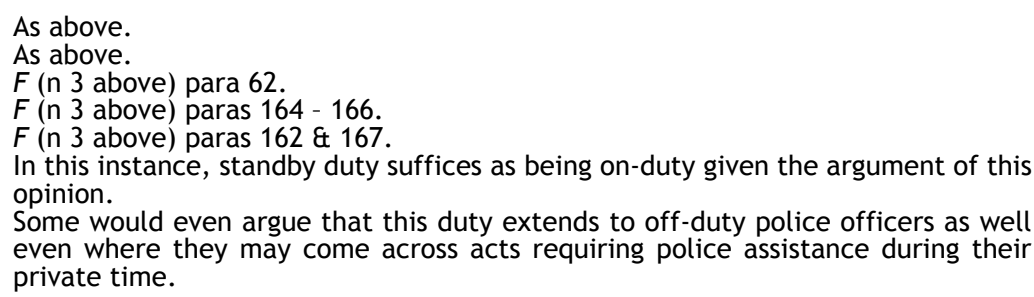

Some would even argue that this duty extends to off-duty police officers as well even where they may come across acts requiring police assistance during their private time. 
that the state is liable. The fact that he was not in uniform or easily identifiable as a policeman is immaterial. ${ }^{93}$ It must be borne in mind however that she drew the conclusion that he was a policeman given she had seen police dockets and a police radio. However, that speaks to reasonableness and is dealt with below.

(b) The second approach of Yacoob $J$ is to focus on the reasonableness of F's conduct in determining whether Van Wyk was a policeman. Yacoob $J$ argues that Van Wyk did not offer a lift to $F$ in his capacity as a policeman and thus offered no official police promise of safe carriage to her. ${ }^{94}$ While it must be conceded that a policeman cannot indemnify anyone to whom he offers a lift a completely safe journey against all forms of harm, it is well within society's remit to expect a policeman not to harm such persons himself. Further, it would not be unreasonable to expect a policeman to fulfil his general duty to protect $F$ against external and intervening factors that would cause $F$ harm where he had the means and ability to protect her.

Further, it does not address the fact that he utilised the property of the state (which was what $F$ based her reasonable deduction that he was a policeman on) to further his own ends. It is submitted that in cases such as these, the 'creation of risk' theory or 'enterprise' theory would serve the purposes of interpreting the vicarious liability test. ${ }^{95}$ This is by virtue of the fact that it was the state's property and employment of the policeman that enabled this policeman to rape $F$, irrespective of how remotely that may have occurred in terms of causation. The fact that he was in possession of and able to use property of the state and was acting under a state mandate brought about by his employment, carries with it a certain degree of authority that can induce any person to place their trust in the possessor/ employee. Mogoeng $\mathrm{CJ}$ does find liability due to these considerations however stops short of affirming that the theory is a legitimate one that can be relied upon in proving a sufficiently close link. ${ }^{96}$ While many may criticise this approach as casting the net too widely and making the employer susceptible to many more instances of liability where they would not normally be held accountable within the framework of the established test for vicarious liability, this is unlikely to occur. ${ }^{97}$ However, the 'creation of risk theory' may indicate which factors, if any, exist at the time that the delict was

$F$ (n 3 above). Applicant's Affidavit paras 26 \& 28.

$F$ (n 3 above) para 169.

Calitz (n 38 above).

$F$ (n 3 above) paras $80-81$.

$F$ (n 3 above) para 84 . It must be noted that despite Calitz's extensive commentary on the use of risk theory as an alternate basis of founding vicarious liability, the decisions of the Constitutional Court and Calitz's own later writings concede that with the decision in $K$, the use of the risk theory in our law is slim. This is even despite the fact that it is used widely in many other jurisdictions in other scenarios. See K Calitz 'The close connection test for vicarious liability' (2007) 18 Stellenbosch Law Review 451. 
committed that would allow a court to better examine the trust aspect that it necessarily gives rise to.

Further, Yacoob $\mathrm{J}$ asserts that in seeing the policeman pursue his own private ends, $\mathrm{F}$ could have never thought him to be on duty and thus any reliance on Van Wyk would be classified as being unreasonable. ${ }^{98}$ This assertion is problematic as it places a burden on a person who may be in a vulnerable position at the time to search for an alternative source of help where a policeman may be present and may be their only chance of getting help. While it can be conceded that gaining assistance from a sober policeman/person is preferable, where there is no alternative avenue of help, it is not unreasonable that help should be sought from a policeman considering the trust that can be placed in them. This is especially the case, as was the situation with $\mathrm{F}$, where they are particularly vulnerable.

However, Yacoob J's determination that F's conduct was unreasonable requires further comment. It would seem that from his criticism of F's election to seek help from the policeman, Yacoob J expected F, a thirteen-year old girl, to behave in a 'reasonable' way that failed to take into consideration the very factors that make this case different. In applying a degree of reasonableness akin to the reasonable man test and in referring strictly to objectively reasonable conduct, Yacoob J incorrectly applied the very thesis of the vicarious liability test: an examination of fact and law that bears in mind both subjective and objective factors to be considered. ${ }^{99}$

Whereas Kruger $v$ Coetzee ${ }^{100}$ developed the traditional reasonable man test and set the applicable objective standard of conduct, ${ }^{101}$ our law has since progressed to include some kind of subjective consideration into the test depending on the facts and circumstances of the scenario at hand. This is owing to the fact that our law recognises that an artificial and objectively set standard of conduct applied indiscriminately could result in disingenuous results. ${ }^{102}$ This is reflected in how professional conduct (in the medical field) is judged differently to the conduct of an ordinary person for example, as per Van Wyk v Lewis. ${ }^{103}$ This is of importance and relevance when questioning whether there is a sufficiently close connection between the delict and the employers interest because these considerations - namely, whether the conduct of the harmed person was reasonable bearing in mind their subjective conditions will yield a just result.

\footnotetext{
$98 \quad F$ (note 3 above) para 170.

99 Rabie (n 40 above).

100 Kruger $v$ Coetzee 19662 SA 428 (A)

101 See eg Herschel v Murpe 19543 SA 464 (A) at 477 and S v Burger 19754 SA 877

1 (A).

102 J Burchell Principles of Criminal Law (2005) 525.

103 Van Wyk v Lewis 1924 AD 438.
} 
In the absence of some form of subjectivisation, academics believe that the test may either result in too strict liability or in liability being escaped altogether. This is a trend in our law that is reflected by developing precedent such as $S \vee V a n A s, 104$ in which our court adapted the test to being about the reasonable man in the position of the accused. ${ }^{105}$ Similarly with $S \vee$ Ngema which held that the test for negligence in our law is still objective but it should be applied according to the standard of the reasonable person of the same background, educational level, culture, sex and race as the accused. ${ }^{106}$ Thus when determining the reasonableness of $F$ 's conduct, it should be evaluated in terms of the reasonable person in the position of F. ${ }^{107}$ Her trust in Van Wyk and whether that created a sufficiently close connection should be evaluated through this scheme as opposed to the removed standard of reasonableness that Yacoob J applied.

Thus when Yacoob J speaks of F's vulnerability, her youth, her biological sex and her fear, ${ }^{108}$ he should instead have evaluated the reasonableness of F's conduct within the confines of those same factors. At the time when this delict was committed, $\mathrm{F}$ a 13 year-old girl child, alone, at night, stranded, potentially under the influence of alcohol, separated from her party that she was with that evening, with no alternative means to gain transport to go home and who was harassed by a person she thought to be a policeman. It is submitted that in light of those factors, F's reliance in the policeman was reasonable. This is bearing in mind that a 13 year-old in those circumstances having seen police dockets in the car as well as the police radio, would have most likely drawn the same conclusion, namely that he was a policeman and that she was deserving of some protection from him - even against his own nefarious intentions.

It is submitted that if Yacoob $\mathrm{J}$ correctly applied the test, he would have found the conduct of a vulnerable and distressed $F$ to be reasonable. The use of reasonable reliance therefore to supplement the thinking within the existing sufficiently close connection test as established by $K$, further limits the true intention of vicarious liability in a constitutional era to be thwarted. In this way, the applicable thinking to the component parts of the existing framework is aligned to the overarching thrust of the test and thus allows for a more congruent result to be attained.

04 S v Van As 19762 SA 291 (A).

105 Own emphasis.

106 S V Ngema 19922 SA 651 (D). This case was to determine the reasonableness of the conduct of the accused with respect to the charge of homicide.

107 While these cases are criminal cases, it must be borne in mind that the law of delict is a civil case and a lower standard of proof applies. Thus, if that is the test for a criminal case with a higher burden of proof, then it should equally apply to 108 the law of delict.

$108 F$ (n 3 above) paras 170 - 172. 


\section{Conclusion}

The critique I offer illustrates how the sufficiently close connection aspect of the course and scope requirement of the vicarious liability test may, despite the authoritative pronouncements of the CC, still result in decisions which shock our collective sense of justice in that upon a technical application, the state may escape liability where one of its functionaries breaches a clear and compulsory duty of protection to a vulnerable person.

It is hoped that by focusing on Yacoob $\mathrm{J}$ and Jafta J's dissent, I have been able to illustrate three further conceptual tools that may be utilised to further supplement and thus enhance the test for vicarious liability as developed in $K$, namely (1) the clarification of standby duty and what it means; (2) the discussion of reasonable reliance and (3) the possibility of utilising the enterprise theory as a means to establish factors which bolster a conclusion of reasonableness all go some way ensuring that, as students, academics and practitioners, we follow the advice of O'Regan $\mathrm{J}$, and guide the courts to:

[T]ake into account the importance of the constitutional role entrusted to the police and the importance of nurturing the confidence and trust in the police, in order to ensure that their role is successfully performed. ${ }^{109}$ 